\title{
Ion Effects on the Uptake of Uranium by Chlorella regularis ${ }^{\dagger}$
}

\author{
Akira NaKajima, Takao Horikoshi and Takashi SaKaguchI \\ Department of Chemistry, Miyazaki Medical College, Kiyotake, \\ Miyazaki 889-16, Japan \\ Received October 16, 1978
}

\begin{abstract}
The effect of various cations and anions on the uptake of uranium by Chlorella regularis was examined.

The uptake of uranium was hindered by phosphate and carbonate ions and was not affected by cations (sodium, potassium, ammonium, magnesium, calcium, manganese, cobalt, nickel, and zinc ions), nitrate, sulfate, and thiosulfate ions. The amounts of uranium taken up by $C$. regularis rapidly decreased with increasing the concentration of phosphate ion in the uranium solution. The amounts of uranium taken up by $C$. regularis also rapidly decreased with increasing the concentration of sodium hydrogencarbonate in the uranium solution. The amounts of uranium taken up by $C$. regularis in the uranium solution containing $1.196 \times 10^{-3} \mathrm{M} /$ liter of sodium hydrogencarbonate were the largest at $\mathrm{pH} 5$ and rapidly decreased in both low and high $\mathrm{pH}$ regions. The compositions of the chemical species of U(VI) in the carbonate solution were calculated, of which results suggested that carbonate ion formed the stable complex ions with uranyl ion, such as $\mathrm{UO}_{2}\left(\mathrm{CO}_{3}\right)_{2}{ }^{2-}$ or $\mathrm{UO}_{2}\left(\mathrm{CO}_{3}\right)_{3}{ }^{4-}$, which were not taken up by $C$. regularis.

From these results, we suggested that the uranium was taken up by $C$. regularis as the cation form $\left(\mathrm{UO}_{2}{ }^{2+}\right.$ or $\left.\mathrm{UO}_{2} \mathrm{OH}^{+}\right)$, and Chlorella cells took up uranium in exchange for their protons in analogy with some organic chelating agents.
\end{abstract}

In the previous paper, ${ }^{13}$ we reported that Chlorella regularis took up a large amount of uranium. We also observed that the uptake of uranium by $C$. regularis was rapid, not so affected by light, temperature, and metabolic inhibitors, and that most of uranium taken up by $C$. regularis was easily released by EDTA solution and mainly distributed in the $26,000 \times g$ precipitate of the cell homogenate. These results suggested that the uptake of uranium by $C$. regularis almost depended upon the physical adsorption on the cell surface, but not upon the biological activity, and that the uranium in the algal cells was coupled with the ligands, which was easily substituted with EDTA.

In this paper, we report the further investigations on the uptake of uranium by $C$. regularis, especially the effect of various ions

$\uparrow$ Studies on the Accumulation of Heavy Metal Elements in Biological Systems. Part V. See reference 1). This work was presented at the Annual Meeting of Agricultural Chemical Society of Japan held on April 3, 1978, Nagoya. on the uptake of uranium for the basic analysis of the recovery of uranium from the aqueous systems.

\section{MATERIALS AND METHODS}

Organism. Chlorella regularis $\mathrm{S}-50$ kindly supplied from the Yakult Institute for Microbiological Research, Tokyo, was used throughout the experiments.

Cultivation of $C$. regularis and preparation of the scalded Chlorella cells. The cultivation method of C. regularis and the preparation of the scalded Chlorella cells were described elsewhere. ${ }^{1)}$

Uptake of uranium by Chlorella cells. The living or the scalded cells were suspended in 1 liter of the solution containing $1 \mathrm{ppm}$ of uranium and the desired concentration of other ions. The $\mathrm{pH}$ of the suspension was adjusted to the desired value with $0.1 \mathrm{~N} \mathrm{HCl}$ or $0.1 \mathrm{~N}$ $\mathrm{NaOH}$. Uranium was applied as $\mathrm{UO}_{2}\left(\mathrm{CO}_{3}\right)_{3}{ }^{4-}$. The uptake of uranium was carried out at $30^{\circ} \mathrm{C}$ with aeration under the illumination of 20,000 lux. After $1 \mathrm{hr}$, the cells taken up uranium were collected by centrifugation, washed 3 times with distilled water, and then lyophilized.

Determination of uranium in Chlorella cells. Ura- 
nium in the dry cells was determined by X-ray fluorescence analysis. The measurements details were described elsewhere. ${ }^{1)}$

\section{RESULTS AND DISCUSSION}

Effect of various cations on the uptake of uranium by $C$. regularis

The effect of various cations on the uptake of uranium by $C$. regularis at pH 5 and 8 was investigated, of which results were shown in Fig. 1. For $\mathrm{Co}^{2+}, \mathrm{Ni}^{2+}, \mathrm{Cu}^{2+}$, and $\mathrm{Zn}^{2+}$, the experiments were carried out at $\mathrm{pH} 5$ only because the hydroxides of these cations precipitated at $\mathrm{pH} 8$. Figure 1 indicated that most cations except cupric ion scarcely affected the uptake of uranium by $C$. regularis. In the case of cupric ion, $10^{-3} \mathrm{eq} /$ liter of cupric ion sufficiently damaged $C$. regularis, ${ }^{2}$ which increased the capacity of the uptake of uranium by Chlorella cells in the same manner as the scalded cells. ${ }^{13}$

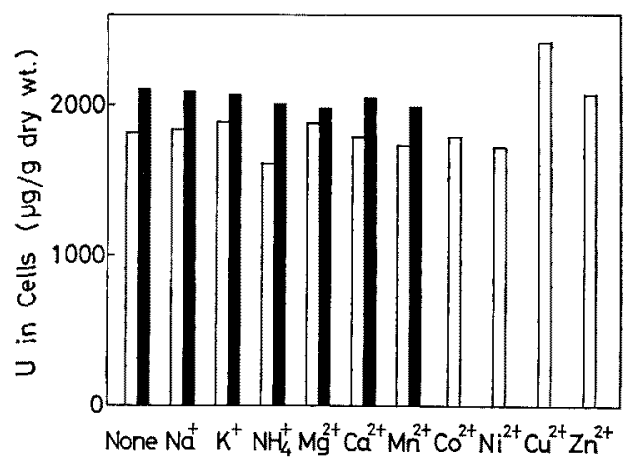

Fig. 1. Effect of Various Cations on the Uptake of Uranium by $C$. regularis.

The uptake of uranium was carried out in the uranium solution containing $10^{-3} \mathrm{eq} /$ liter of each cation (applied as chloride) at pH 5 ( $\square$ ) and 8 (回). The initial cell concentrations expressed as the packed cell volume were $1.05 \mathrm{ml} / \mathrm{liter}(\mathrm{pH}$ 5) and $1.15 \mathrm{ml} /$ liter (pH 8).

Effect of various anions on the uptake of uranium by $C$. regularis

The effect of various anions on the uptake of uranium by $C$. regularis at $\mathrm{pH} 5$ and 8 was investigated, of which results were shown in Fig. 2. Figure 2 indicated that the uptake of uranium by $C$. regularis was hindered by carbo-

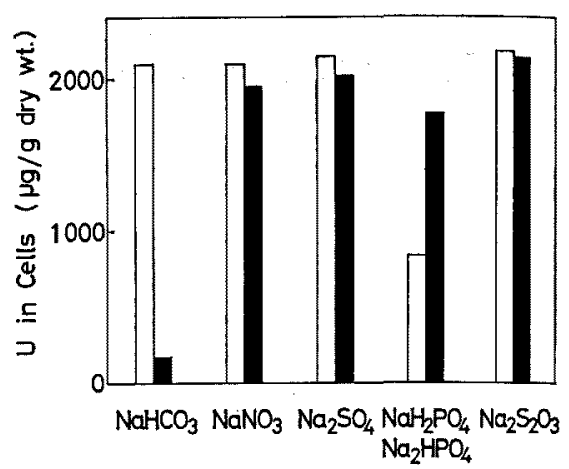

FIG. 2. Effect of Various Anions on the Uptake of Uranium by $C$. regularis.

The uptake of uranium was carried out in the uranium solution containing $10^{-8} \mathrm{eq} /$ liter of each anion(applied as sodium salt) at $\mathrm{pH} 5(\square)$ and 8 ( $\square)$. The initial cell concentration was $1.00 \mathrm{ml} /$ liter.

nate ion at $\mathrm{pH} 8$ and phosphate ion at $\mathrm{pH} 5$ and 8 . On the other hand, nitrate, sulfate, and thiosulfate ions did not affect the uptake of uranium. Figure 1 also showed no influence of the chloride ion on the uptake of uranium by $C$. regularis.

It was seen that phosphate and carbonate ions affected the uptake of uranium by $C$. regularis, so we made further studies concerned with both anions.

Effect of phosphate ion on the uptake of uranium by $C$. regularis

The uptake of uranium by the living and scalded Chlorella cells from the uranium solution containing various concentrations of phosphate ion at pH 8 was investigated, of which results were shown in Fig. 3. Figure 3 indicated that with increasing the concentration of phosphate ion in the solution, the amounts of uranium taken up by both living and scalded Chlorella cells rapidly decreased, and $10^{-3} \mathrm{M}$ / liter of phosphate ion reduced the amounts of uranium taken up by the living Chlorella cells down to $4.2 \%$ of that in the solution containing uranium only. In Fig. $2,10^{-3} \mathrm{eq} /$ liter of anions were applied in the uranium solution (at $\mathrm{pH} 5$ sodium dihydrogenphosphate and at $\mathrm{pH} 8$ disodium hydrogenphosphate were used) so the molar concentration of phosphate ion at $\mathrm{pH} 5$ was twice as that at $\mathrm{pH} 8$. Accordingly, it 


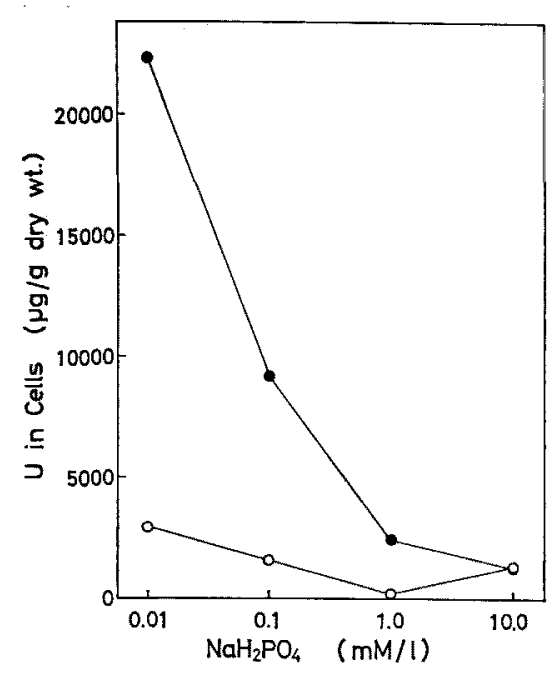

Fig. 3. Effect of Various Concentrations of Disodium Hydrogenphosphate on the Uptake of Uranium by Chlorella Cells.

The uptake of uranium by the living $(0)$ and the scalded (0) Chlorella cells was carried out in the uranium solution containing $0 \sim 10^{-2} \mathrm{M} /$ liter of disodium hydrogenphosphate at $\mathrm{pH} 8$. The initial cell concentrations were $0.22 \mathrm{ml} /$ liter (living) and $0.10 \mathrm{ml} /$ liter (scalded).

was considered that the decrease of the amount of uranium taken up by Chlorella cells at $\mathrm{pH} 5$ was due to the larger amount of phosphate ion in the uranium solution than that at $\mathrm{pH} 8$.

Uranyl ion forms fairly stable complex ions with dihydrogenphosphate ion and hydrogenphosphate ion such as $\mathrm{UO}_{2}\left(\mathrm{H}_{2} \mathrm{PO}_{4}\right)_{3}{ }^{-}$or $\mathrm{UO}_{2}\left(\mathrm{HPO}_{4}\right)_{2}{ }^{2-}$, which will not be taken up by Chlorella cells.

The phosphate ion scarcely exists in the natural sea water and therefore little affects the recovery of uranium from sea water by microalgae. On the other hand, the carbonate ion exists in large amounts in the natural sea water so that we investigated minutely the effect of the carbonate ion on the uranium uptake by Chlorella cells.

Effect of carbonate ion on the uptake of uranium by $C$. regularis

First, the uptake of uranium by the living and scalded Chlorella cells from the uranium solution containing various concentrations of sodi-

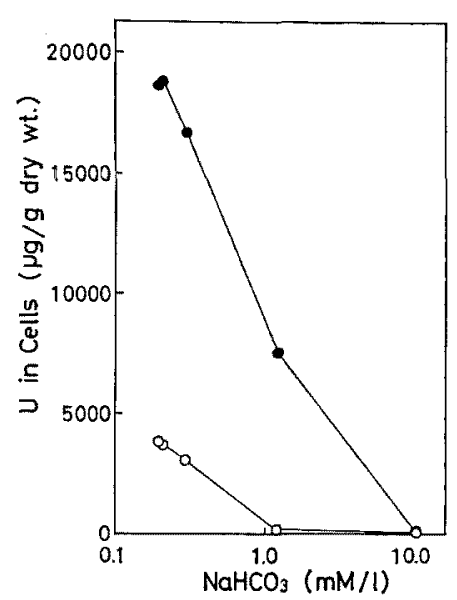

FIG. 4. Effect of Various Concentrations of Sodium Hydrogencarbonate on the Uptake of Uranium by Chlorella Cells.

The uptake of uranium by the living (O) and the scalded (e) Chlorella cells was carried out in the uranium solution containing $1.96 \times 10^{-4} \sim 1.02 \times 10^{-2}$ $\mathrm{M} /$ liter of sodium hydrogencarbonate at $\mathrm{pH} 8$. The initial cell concentrations were $0.26 \mathrm{ml} / /$ liter (living) and $0.12 \mathrm{ml} /$ liter (scalded).

um hydrogencarbonate at $\mathrm{pH} 8$ was investigated, of which results were shown in Fig. 4. Figure 4 indicated that with increasing the concentration of sodium hydrogencarbonate in the uranium solution, the amounts of uranium taken up by both living and scalded Chlorella cells decreased rapidly, and $1.02 \times 10^{-2} \mathrm{M} /$ liter of sodium hydrogencarbonate reduced the amounts of uranium taken up by both living and scalded Chlorella cells down to zero.

Uranyl ion forms very stable complexes with carbonate ion, $\mathrm{UO}_{2} \mathrm{CO}_{3}, \mathrm{UO}_{2}\left(\mathrm{CO}_{3}\right)_{2}{ }^{2-}$, and $\mathrm{UO}_{2}\left(\mathrm{CO}_{3}\right)_{3}{ }^{4-}$, which will not be taken up by Chlorella cells. The compositions of the chemical species of U(VI) ion in the solution containing various concentrations of sodium hydrogencarbonate at $\mathrm{pH} 8$, calculated according to the Ogata's method, ${ }^{3)}$ were listed in Table $\mathrm{I}$. Table I indicated that in the solution containing $1.96 \times 10^{-4} \mathrm{M} /$ liter of sodium hydrogencarbonate at $\mathrm{pH} 8, \mathrm{UO}_{2}(\mathrm{OH})_{3}{ }^{-}$was the main species, but with increasing the concentration of sodium hydrogencarbonate $\mathrm{UO}_{2}\left(\mathrm{CO}_{3}\right)_{3}{ }^{4-}$ progressively increased. In the solution containing $1.02 \times 10^{-2} \mathrm{M} /$ liter of sodium hydrogen- 
Table I. Composition of the Chemical Species of U(VI) Ion in the Solution Containing Various Concentrations of Sodum Hydrogencarbonate

\begin{tabular}{lccccc}
\hline Chemical species & \multicolumn{5}{c}{$\left[\mathrm{NaHCO}_{3}\right]\left(10^{-3} \mathrm{M} /\right.$ liter $)$} \\
& 0.196 & 0.206 & 0.296 & 1.196 & 10.20 \\
\hline$\left[\mathrm{UO}_{2}{ }^{2+}\right]$ & $0.00 \%$ & $0.00 \%$ & $0.00 \%$ & $0.00 \%$ & $0.00 \%$ \\
{$\left[\mathrm{UO}_{2} \mathrm{OH}^{+}\right]$} & 0.01 & 0.01 & 0.01 & 0.00 & 0.00 \\
{$\left[\mathrm{UO}_{2}(\mathrm{OH})_{2}\right]$} & 0.78 & 0.78 & 0.77 & 0.34 & 0.00 \\
{$\left[\mathrm{UO}_{2}(\mathrm{OH})_{3}{ }^{-}\right]$} & 98.60 & 98.50 & 97.21 & 42.88 & 0.12 \\
{$\left[\mathrm{UO}_{2} \mathrm{CO}_{3}{ }^{3}\right.$} & 0.01 & 0.01 & 0.02 & 0.04 & 0.04 \\
{$\left[\mathrm{UO}_{2}\left(\mathrm{CO}_{3}\right)_{2}{ }^{2-}\right]$} & 0.04 & 0.04 & 0.08 & 0.60 & 0.12 \\
{$\left[\mathrm{UO}_{2}\left(\mathrm{CO}_{3}\right)_{3}{ }^{2-}\right]$} & 0.56 & 0.65 & 1.90 & 56.13 & 99.76 \\
\hline
\end{tabular}

Table II. Compositions of the Chemical Species of U(VI) Ion in the Solution Containing $1.196 \times 10^{-3} \mathrm{M} / \mathrm{L}$ tTer of Sodium Hydrogencarbonate at Various $\mathrm{pH}$ Values

\begin{tabular}{lccrrrr}
\hline Chemical species & \multicolumn{7}{c}{ pH value } \\
& 4 & 5 & \multicolumn{1}{c}{6} & \multicolumn{1}{c}{7} & \multicolumn{1}{c}{8} & \multicolumn{1}{c}{9} \\
\hline$\left[\mathrm{UO}_{2}{ }^{2+}\right]$ & $90.57 \%$ & $40.94 \%$ & $1.93 \%$ & $0.00 \%$ & $0.00 \%$ & $0.00 \%$ \\
{$\left[\mathrm{UO}_{2} \mathrm{OH}{ }^{+}\right]$} & 9.05 & 40.94 & 19.32 & 0.61 & 0.00 & 0.00 \\
{$\left[\mathrm{UO}_{2}(\mathrm{OH})_{2}\right]$} & 0.06 & 2.58 & 12.19 & 3.86 & 0.34 & 0.04 \\
{$\left[\mathrm{UO}_{2}(\mathrm{OH})_{3}{ }^{-}\right]$} & 0.00 & 0.32 & 15.34 & 48.64 & 42.88 & 45.42 \\
{$\left[\left(\mathrm{UO}_{2}\right)_{2}(\mathrm{OH})_{2}{ }^{2+}\right]$} & 0.00 & 1.54 & 0.34 & 0.00 & 0.00 & 0.00 \\
{$\left[\left(\mathrm{UO}_{2}\right)_{3}(\mathrm{OH})_{3}{ }_{3}^{+}\right]$} & 0.00 & 0.14 & 2.36 & 0.00 & 0.00 & 0.00 \\
{$\left[\mathrm{UO}_{2} \mathrm{CO}_{3}\right]$} & 0.31 & 13.54 & 45.39 & 3.65 & 0.04 & 0.00 \\
{$\left[\mathrm{UO}_{2}\left(\mathrm{CO}_{3}\right)_{2}{ }^{2-}\right]$} & 0.00 & 0.00 & 2.39 & 4.87 & 0.60 & 0.06 \\
{$\left[\mathrm{UO}_{2}\left(\mathrm{CO}_{3}\right)_{3}{ }^{4-}\right]$} & 0.00 & 0.00 & 0.74 & 38.37 & 56.13 & 54.47 \\
\hline
\end{tabular}

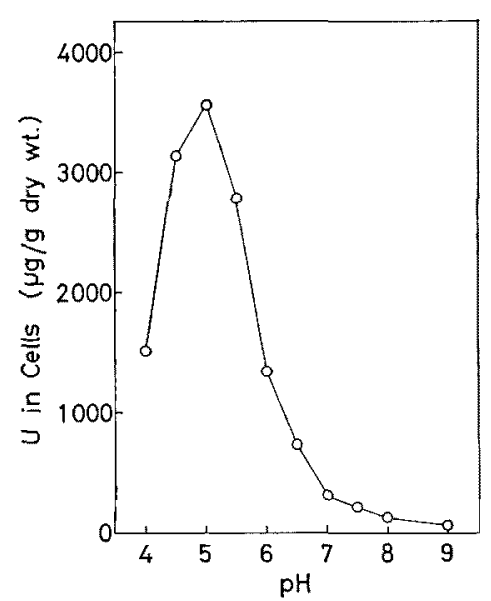

Fig. 5. Effect of $\mathrm{pH}$ in the Uranium Solution Containing $1.196 \times 10^{-3} \mathrm{M} /$ liter of Sodium Hydrogencarbonate on the Uptake of Uranium.

The uptake of uranium by C. regularis was carried out in the uranium solution containing $1.196 \times 10^{-3} \mathrm{M} / \mathrm{liter}$ of sodium hydrogencarbonate at $\mathrm{pH} 4 \sim 9$. The initial cell concentration was $0.28 \mathrm{ml} / \mathrm{liter}$.

carbonate, $99.76 \%$ of U(VI) ion were existed as $\mathrm{UO}_{2}\left(\mathrm{CO}_{3}\right)_{3}{ }^{4-}$, which was not taken up by Chlorella cells.
Next, the uptake of uranium by the living Chlorella cells from the uranium solution containing $1.196 \times 10^{-3} \mathrm{M} /$ liter of sodium hydrogencarbonate at various $\mathrm{pH}$ values was investigated, of which results were shown in Fig. 5. Figure 5 indicated that the amounts of uranium taken up by the living Chlorella cells was the largest at $\mathrm{pH} 5$ and rapidly dropped down in both high and low $\mathrm{pH}$ regions. At $\mathrm{pH} 8$ the amounts of uranium taken up by the living Chlorella cells became to $3.5 \%$ of that at $\mathrm{pH} 5$. In the previous paper, ${ }^{1)}$ we reported that in the uranium solution containing $1.96 \times 10^{-4} \mathrm{M} /$ liter of sodium hydrogencarbonate the amounts of uranium taken up by Chlorella cells were fairly large in the $\mathrm{pH}$ range between 7 and 9 , so that in the present experiment the rapid decrease of the uranium content in the high $\mathrm{pH}$ region was attributed to the high concentration of sodium hydrogencarbonate in the solution. The compositions of the chemical species of U(VI) ion in the solution containing $1.196 \times 10^{-3} \mathrm{M} /$ liter of sodium hydrogencarbonate at various $\mathrm{pH}$ values were 
also calculated and listed in Table II. Table II indicated that at $\mathrm{pH} 5 \mathrm{UO}_{2}{ }^{2+}$ and $\mathrm{UO}_{2} \mathrm{OH}^{+}$ were the main species but at $\mathrm{pH} 8 \mathrm{UO}_{2}\left(\mathrm{CO}_{3}\right)_{3}{ }^{4-}$ and $\mathrm{UO}_{2}(\mathrm{OH})_{3}{ }^{-}$became majority, and then the amounts of uranium taken up by Chlorella cells decreased. From Figs. 4, 5 and Tables I, II, we suggested that $\mathrm{UO}_{2}{ }^{2+}$ and $\mathrm{UO}_{2} \mathrm{OH}^{+}$were taken up by Chlorella cells but $\mathrm{UO}_{2}\left(\mathrm{CO}_{3}\right)_{3}{ }^{4-}$ was scarcely taken up. On the other hand, $\mathrm{UO}_{2}(\mathrm{OH})_{3}{ }^{-}$is fairly unstable compared with $\mathrm{UO}_{2}\left(\mathrm{CO}_{3}\right)_{3}{ }^{4-}$ so that the formation of $\mathrm{UO}_{2}-$ $(\mathrm{OH})_{3}{ }^{-}$do not hinder strongly the uranium uptake by Chlorella cells.

In Fig. 5, the amounts of uranium taken up by Chlorella cells were fairly decreased in the low $\mathrm{pH}$ region below 5 , and at $\mathrm{pH} 4$ the uranium content was about $55.6 \%$ of that at $\mathrm{pH} 5$. The similar results were also observed in the solution containing $1.96 \times 10^{-4} \mathrm{M} /$ liter of sodium hydrogencarbonate, ${ }^{11}$ and the uranium content at $\mathrm{pH} 4$ was about $42.3 \%$ of that at $\mathrm{pH} 5$. These results meant that the decrease of uranium taken up by Chlorella cells in the low $\mathrm{pH}$ region did not so depend on the concentration of sodium hydrogencarbonate. So we suggested that Chlorella cells took up uranium in exchange for their protons in analogy with some organic chelating agents according to the following equation ( $\mathrm{L}$ means algal cells as ligands):

$$
\mathrm{LH}_{2}+\mathrm{UO}_{2}{ }^{2+} \rightleftarrows \mathrm{LUO}_{2}+2 \mathrm{H}^{+} \text {. }
$$

In the low $\mathrm{pH}$ region, the formation of $\mathrm{H}^{+}$was depressed and the equilibrium was shifted to left, and then the amounts of uranium taken up by Chlorella cells decreased. The formation constant of $\mathrm{LUO}_{2}$ was so small in comparison with $\mathrm{UO}_{2}\left(\mathrm{CO}_{3}\right)_{3}{ }^{4-}$, that in the high
$\mathrm{pH}$ region most of uranyl ion existed as $\mathrm{UO}_{2^{-}}$ $\left(\mathrm{CO}_{3}\right)_{3}{ }^{4-}$ and not as $\mathrm{LUO}_{2}$, then the amounts of uranium taken up by Chlorella cells decreased in the high $\mathrm{pH}$ region.

We observed: Cations scarcely affected the uptake of uranium by C. regularis. Phosphate and carbonate ions, which formed stable complex ions with uranyl ion, hindered the uptake of uranium by $C$. regularis. The amounts of uranium taken up by Chlorella cells rapidly decreased with increasing the concentration of phosphate ion or carbonate ion in the solution. The amounts of uranium taken up by $C$. regularis in the solution containing $1.196 \times 10^{-3} \mathrm{M} /$ liter of sodium hydrogencarbonate were the largest at $\mathrm{pH} 5$ and rapidly decreased in both high and low $\mathrm{pH}$ regions.

From these results, we suggested that uranium was taken up as the cation forms $\left(\mathrm{UO}_{2}{ }^{2+}\right.$ and $\mathrm{UO}_{2} \mathrm{OH}^{+}$) by C. regularis and the Chlorella cells took up uranium in exchange for their protons in analogy with some organic chelating agents.

Acknowledgement. The authors were awfully indebted to Dr. I. Tagawa of the Agricultural Experiment Station of Miyazaki Prefecture for his kind permitting to use the X-ray fluorescence spectrometer. This work was supported in part by a grant from Ministry of Education of Japan.

\section{REFERENCES}

1) T. Horikoshi, A. Nakajima and T. Sakaguchi, Agric. Biol. Chem., 43, 617 (1979).

2) T. Sakaguchi, T. Horikoshi and A. Nakajima, Nippon Nôgeikagaku Kaishi, 51, 497 (1977).

3) N. Ogata, N. Inoue and H. Kakihana, Bull. Soc. Sea Water Sci. Japan, 24, 19 (1970); idem, J. Atomic Energy Soc. Japan, 13, 560 (1971). 